\title{
ŚMIERĆ INTELEKTUALISTY. NARESZCIE!
}

Jacek Zych

Uniwersytet Warszawski

Ale, jak wykażemy, nie ma ani przedmiotu nauczania, ani uczącego, ani nauczającego, ani sposobu nauczania; a zatem nie ma żadnej nauki.

Sekstus Empiryk, Przeciw uczonym

\section{/// 1. Wstęp ${ }^{1}$}

$\mathrm{Na}$ obecnym etapie dyskusji o uniwersytecie porównywanie go z fabryką stało się już nieomal banałem. Jednym z wymiarów tej szczególnej proletaryzacji jest oczywiście wzrost liczby studentów - od początku lat 90 . liczba studentów wzrosła z około 400000 do niemalże dwóch milionów w latach 2005-2010, by następnie spaść do i tak potężnej liczby $1300000 \mathrm{w}$ okresie 2016-2019 (patrz Aneks, Wykres 1)². Podobny trend oddaje wskaźnik skolaryzacji netto w odniesieniu do szkolnictwa wyższego, czyli odsetek osób w wieku przypisanym do danego kształcenia faktycznie je podejmujących. W 1990 roku współczynnik ten wynosił niecałe 10\%, by szybko wzrosnąć, a w szczytowym okresie, tj. latach 2008-2013, osiagnąć w przybliżeniu $40 \%$, co oznacza, że w tym okresie prawie co druga osoba w wieku 19-24 lata podjęła studia (patrz Aneks, Wykres 2). Od 2013 następuje (niewielki) spadek tego odsetka - do 36,2\% w roku szkolnym 2017/2018.

\footnotetext{
1 Śródtytuły umieszczone w tekście pochodzą od redakcji.

${ }^{2}$ W kontekście proletaryzacji i umasowienia studiów por. słynny opis industrializacji z Manifestu komunistycznego: ,„[..] całe jakby z podziemi wyczarowane masy ludności [...]. Masy robotnicze, stłoczone w fabryce, organizowane są po żołniersku. [...] Ale wraz ze wzrostem przemysłu proletariat nie tylko powiększa się liczebnie; jest on stłaczany w coraz większe masy, siła jego rośnie i coraz bardziej czuje on tę siłę" (Marks, Engels 1949: 30-33).
} 
Na jeszcze większą popularność i dostępność studiów wskazuje współczynnik skolaryzacji brutto, który pokazuje stosunek całej populacji studiujących do ogółu ludności w danym wieku, dzięki czemu uwzględnia osoby przeciagające studia lub podejmujące je w późniejszym okresie życia. Układa się on na wykresie w linię zbliżoną do współczynnika netto, z tym że jest o dziesięć punktów procentowych wyższy (patrz Aneks, Wykres 2).

Wszystkie te trzy parametry tworzą spójny obraz wzrostu wykształcenia wyższego w Polsce. Interpretacji wymaga jedynie pewna rozbieżność między liczbą studentów a współczynnikiem skolaryzacji, który obniża się w mniejszym stopniu i później niż liczba studentów po 2010 roku. Wynika to z ogólnie mniejszej liczebności rocznika wchodzącego w wiek kształcenia akademickiego. Pierwsza dekada XXI wieku to czas, gdy 19 lat kończyły osoby urodzone podczas boomu demograficznego lat 80., stąd tak duża liczba studiujących. Utrzymanie się współczynnika skolaryzacji na wysokim poziomie wynika z tego, że wciąż podobny procentowo odsetek absolwentów szkół średnich decyduje się na studia wyższe, choć w liczbach bezwzględnych jest ich mniej. Za statystyczne podsumowanie zmian można uznać wzrost odsetka osób z wyższym wykształceniem powyżej 25. roku życia - od niecałych 7\% w 1990 do ponad 20\% w ostatnich latach. Aktualnie co czwarty mieszkaniec Polski posiada wyższe wykształcenie (GUS 2018a: 211). Skutki tego zjawiska były wielokrotnie omawiane. Należy do nich inflacja dyplomów nie przekładająca się na satysfakcjonujące miejsca pracy; zmiana charakteru kształcenia wyższego, które przyjmując masowy wymiar bez proporcjonalnego wzrostu nakładów, musiało stracić na jakości; zanik podobno kiedyś istniejącej relacji uczeń-mistrz itp. By jednak dokonać właściwej interpretacji tego fenomenu, trzeba rozważyć, dlaczego właściwie doszło do takiego powiększenia wykształconej populacji?

\section{/// 2. Perspektywa}

Naiwna, zakorzeniona w oświeceniowym myśleniu idealistyczna wizja stopniowego postępu uznaje, że podnoszenie poziomu wykształcenia jest niejako „naturalne” („kaganek oświaty” wreszcie dociera do mas). Gospodarka się rozwija, wymaga więc wykształconych pracowników, ci z kolei dzięki swojemu wykształceniu otrzymują lepsze wynagrodzenie, a praca, która wykonują, daje więcej satysfakcji. Końcowy rezultat to osiagnięcie szczęśliwej stabilizacji, której wzorem przez pewien czas były w Polsce bogate kraje Europy Zachodniej. Tej koncepcji historii, która w wolnym, spokojnym tempie zmierza do szczęśliwego finału, nie da się już utrzymać,

\section{/ 206 STANRZECZY 1[16]/2019}


zważywszy zarówno na krwawe doświadczenia XX wieku, jak i coraz bardziej realny kryzys ekologiczny.

Perspektywa Marksowska, nawet jeśli uwzględnia tzw. postęp a współczesna myśl lewicowa jest coraz bardziej krytyczna wobec tego pojęcia - uzupełnia tę wizję, wprowadzając do niej element ludzkiej sprawczości, tj. element walki klas. Wydarzeń historycznych nie można tłumaczyć teleologicznie, odwołując się do jakiegoś z góry ustanowionego celu, tak jakby ludzkość odgrywała na scenie dramat napisany przez kogoś innego, swego rodzaju boskiego reżysera. Analiza klasowa, tj. analiza świecka ${ }^{3}$, nie poszukuje wyjaśnień w zaświatach, lecz wyjaśnia fenomeny społeczne w odniesieniu do interesów klas składających się na realnie istniejące społeczeństwo. Z tego punktu widzenia pytanie, jakie musimy sobie zadać, brzmi: jaką rolę odegrało rozpowszechnienie wyższego wykształcenia w konflikcie klasowym ostatniego ćwierćwiecza?

\section{/// 3. Intelektualista jako pracownik}

\subsection{Boom edukacyjny w Polsce a rola burżuazji}

Lata 90., w których rozpoczął się ten edukacyjny boom, naznaczone zostały w Polsce pośpiesznym demontażem tego, co można by nazwać ,wschodnioeuropejskim fordyzmem", który przyjął u nas formę tzw. realnego socjalizmu. Dopiero dekada lat 90. zmieniła kompozycję klasowa powojennego społeczeństwa polskiego, która przez cały okres PRL określona była przez nierozstrzygniętą walkę między robotnikami fabrycznymi i biurokracja partyjna, rzekomo ich reprezentująca, a w praktyce zarządzająca wyzyskiem proletariatu fabrycznego ${ }^{4}$. Metoda użyta wówczas przez władzę została już sprawdzona na Zachodzie, więc można było posłużyć się dobrym, importowanym know-how. Ponieważ to wielkie fabryki stanowiły źródło siły robotniczej, właśnie je należało rozmontować, tak jak dokony-

\footnotetext{
${ }^{3}$ Bo przecież, jak pisał Marks (1962a: 457): ,krytyka religii stanowi przesłankę wszelkiej krytyki”. ${ }^{4}$ Klasyczną analizę klasową PRL-u, będąca być może najlepszym polskim tekstem marksistowskim XX-wieku, prezentuje List otwarty do partii Jacka Kuronia i Karola Modzelewskiego z 1965 roku (Kuroń, Modzelewski 2009). Porównaj także pracę Sławomira Magali, pisaną w okresie „Solidarności” pod pseudonimem Stanisław Starski, Walka klas w bęklasowej Polsce (2012) czy pracę Alaina Touraine’a poświęconą „Solidarności” (2010). Zbliżone podejście w stosunku do realiów bloku wschodniego zajmowała zresztą cała niezależna, najbardziej konsekwentna lewica światowa; zob. np. antologię ważnej francuskiej grupy Socialisme ou Barbarie (Amair i in. 2018), prace z kręgu amerykańskiej grupy Johnson-Forest Tendency (np. Lee, Chaulieu, Johnson 1958) czy prace sytuacjonistów (np. Debord 2006).
} 
wało się to na Zachodzie od lat 70. Plan został wdrożony, a wielu byłych pracowników fabryk zasiliło grono bezrobotnych.

Nietzsche twierdzi w swoich Myslach o præesqadach moralnych, że „Praca jest najlepszym policjantem” (1912: 179); historia ostatnich dekad uczy nas jednak, że jeszcze lepszym policjantem jest brak pracy. Wywołanie masowego bezrobocia, czyli bezpośredni efekt likwidacji zakładów przemysłowych, okazało się najlepszym sposobem na pokonanie robotników i skutecznie ich spacyfikowało ${ }^{5}$. Jednak proste pozbawienie wszystkich środków do życia i nadziei na przyszłość nie było politycznie możliwe, należało użyć bardziej wyrafinowanej strategii. Strategię tę określić można jako późnodwudziestowieczne zastosowanie klasycznej zasady divide et impera. Klasa rządząca nie mogła po prostu dokonać frontalnego ataku na klasę pracująca, bo nie miała do tego wystarczającej siły. Tak jak zawsze musiała ją najpierw podzielić. Zgodnie z tym wcale nie wszyscy stali się bywalcami urzędów pracy. Części udało się uzyskać różnego rodzaju świadczenia i opuścić na dobre rynek pracy, inni założyli drobne biznesy, a jeszcze inni musieli rozpocząć funkcjonowanie w półlegalnej strefie drobnych zakładów pracy i doświadczyć wszystkich niedogodności z tym związanych braku formalnych umów, nieograniczonego czasu pracy, arbitralnej władzy drobnych prywaciarzy.

Przez ten pryzmat należy widzieć rozwój szkolnictwa wyższego w Polsce. Młodzież wywodząca się z klasy pracującej, która w innym przypadku powiększyłaby grono pracowników fabrycznych lub też rosnące w zastraszającym tempie szeregi bezrobotnych ${ }^{6}$, otrzymała szansę przedłużenia edukacji i zdobycia wyższego wykształcenia, do niedawna otoczonego prestiżem i gwarantującego awans klasowy. Któż nie złapałby się na taką przynętę? Zresztą, jaka była alternatywa? Uniwersytety szybko wypełniły się studentami i stały się dla wielu przepustką do pracy biurowej, która jednak szybko przestała się wiązać $\mathrm{z}$ satysfakcjonującym zawodem, a często nawet nie gwarantowała szczególnie wysokiego wynagrodzenia. Z punktu widzenia burżuazji spełniły one jednak bardzo ważną funkcję: dały na kilka lat zajęcie milionowej masie młodych ludzi, która w połączeniu z już znajdującymi się na bezrobociu milionami mogłaby stworzyć prawdziwie wybu-

\footnotetext{
${ }^{5}$ Niekoniecznie musi to zakładać, że klasa rządząca miała świadomość, w którym kierunku zmierza. Niemniej jednak, pewne dowody wskazują na to, że burżuazja przewidziała skutki swoich działań i z premedytacją doprowadziła do powstania masowego bezrobocia: ,[...] nie pozostawia watpliwości, że już w roku 1990 przewidywano ponad 25-procentową stopę bezrobocia (razem z ukrytym), a 16-procentowa - już bez ukrytego - miała otwierać obecne stulecie” (Kowalik 2009: 102).

${ }^{6} \mathrm{~W}$ pierwszej dekadzie XXI wieku pozbawiony formalnego zatrudnienia był co piaty członek klasy pracującej (patrz Aneks, Wykres 3).
} 
chową mieszankę. Nie bez znaczenia było też rozbudzenie nadziei związanej ze zdobytym wykształceniem. Niemniej jednak sądzimy, że z punktu widzenia klasy rządzącej najważniejsza korzyść z wysłania tych wszystkich ludzi na uniwersytet była inna. Z perspektywy czasu ocenić można, że rozpowszechnienie się wyższego wykształcenia nie podniosło ani poziomu intelektualnego w społeczeństwie, ani nie wykorzeniło najróżniejszych zabobonów, przesądów i uprzedzeń, ani nie sprawiło nawet, że jest w Polsce trochę sympatyczniej. Wskazuje na to na przykład dość duży sukces nagonki na uchodźców i ogólny autorytarny klimat relacji społecznych? C Czym więc właściwie okazało się kształcenie wyższe?

Dla osób zaznajomionych z krytyką społeczną nie będzie niespodzianką odpowiedź, którą tu zaproponujemy. Nowoczesna władza państwowa jest „jedynie komitetem zarządzającym wspólnymi interesami całej klasy burżuazyjnej" (Marks, Engels 1949: 28), a edukacja jest jednym z organów tego komitetu, mającym za zadanie prowadzić ideologiczne pranie mózgu klasie pracującej, czyli jest, zgodnie z określeniem Louisa Althussera, ideologicznym aparatem państwa. Spośród szeregu ideologicznych aparatów państwowych - państwowego, religijnego, rodzinnego, prawnego, politycznego, związkowego, kulturalnego - Althusser właśnie aparatowi szkolnemu przypisuje wyjątkowo ważna pozycję: „Jednak w tym koncercie jeden ideologiczny aparat państwowy odgrywa po prostu rolę dominująca, chociaż jego muzyce nie użycza się uszu: jest on wszak tak cichy! Chodzi tutaj o Szkołę" (Althusser 2006: 15).

Nie dostrzegamy całej niezwykłości tej sytuacji tylko dlatego, że do niej przywykliśmy. Niemniej jednak, jest ona w skali historycznej niespotykana: „W odróżnieniu od tego, co działo się w niewolniczych i feudalnych formacjach społecznych, reprodukcja kwalifikowanej siły roboczej (chodzi tu o pewną tendencję), nie zachodzi już w ogniu pracy (uczenie się w samym procesie produkcji), lecz w coraz większym stopniu poza produkcja: przez kapitalistyczny system szkolnictwa oraz inne instancje i instytucje" (tamże: 5) ${ }^{8}$. Dzieci odłączane są od rodzin, wyrywane ze swojego środowiska społecznego i latami indoktrynowane: ,[... żaden ideologiczny aparat państwowy nie dysponuje przez tyle lat posłuchem (i - chociaż ma to najmniejsze znaczenie - bezpłatnym) obowiązującym przez 5 lub 6 dni

\footnotetext{
${ }^{7}$ Diagnoza polskiego nowego autorytaryzmu (zob. Gdula 2018).

${ }^{8} \mathrm{~W}$ jeszcze lepszy sposób absurdalność i paradoksalność tego rozwiązania ukazuje klasyczny dla antykapitalistycznego feminizmu tekst pt.: Power of Women and Subversion of the Community Mariarosy Dalla Costy i Selmy James: „Kapitalizm jest pierwszym systemem, gdzie dzieci wyzyskiwanych sa dyscyplinowane i edukowane w instytucjach zorganizowanych i kontrolowanych przez klasę rządząca”" (Dalla Costa, James 1972: 7).
} 
w tygodniu po 8 godzin dziennie wszystkie dzieci kapitalistycznej formacji społecznej" (tamże: 15)9. Zadanie szkoły zakłada wpojenie uczniom określonego zbioru idei, lecz nawet ważniejsze jest to, że szkoła wdraża określone zachowania i afekty. Inaczej mówiąc, szkoła uczy punktualności, posłuszeństwa, znoszenia nudy i bezsensu, umiejętności siedzenia wiele godzin w jednym miejscu, tolerowania arbitralnej władzy, akceptacji systemu ocen będącego prefiguracją systemu płac, pogardy dla innych, milczenia i mówienia na rozkaz, identyfikacji narodowej, szacunku dla własności prywatnej, podziwu dla władców i czci dla instytucji państwowych.

Althusser kładzie w swoim tekście nacisk na materialność ideologii i my również przychylamy się do tego stanowiska: „ideologia istnieje materialnie" (tamże: 19). Materializuje się ona w instytucjach szkolnych, nauczycielach oddanych wykonywaniu pedagogicznych rytuałów, klasach, stopniach, czerwonych paskach i uwagach w dzienniczku, a obecnie również w elektronicznych systemach służących ocenianiu i kontrolowaniu uczniów. W tym sensie, ideologia zawsze istnieje w aparacie i jego praktyce lub praktykach" (tamże: 20). Celem tej ideologicznej tresury jest uformowanie „posłusznego podmiotu”, mówiąc językiem foucaultowskim - ujarzmienie zasobów ludzkich przechodzących przez tę szczególną taśmę produkcyjna. Skrótowo i metaforycznie Althusser podsumowuje efekt działania takiego systemu za pomocą słynnego obrazu policjanta krzyczącego do przypadkowej osoby na ulicy. Działanie policjanta można sobie wyobrazić „na wzór najbanalniejszego wezwania policyjnego (albo nie) wszystkich czasów: Hej, ty tam!'” (tamże: 23). Chodzi o stworzenie, czy też, jeśli trzymać się metafory fabryki, wyprodukowanie podmiotu, który nie tylko sam pomaszeruje na komisariat na zawołanie policjanta, ale równie karnie odpowie na wezwanie (,interpelację”, zgodnie z terminologia Althusserowska) urzędnika państwowego, księdza, szefa. Mówiąc Althusserem (tamże: 27): „Tak, podmioty maszeruja całkiem same”, by spełnić swe obowiązki pracownika, obywatela, osoby wierzącej. Tę właśnie zbawienną uległość ma zapewnić system edukacji. Ma on zapewnić „reprodukcję siły roboczej” (tamże: 4-5), która swoja pracą sama tworzy system ją wyzyskujący. Ma on dokonać „,reprodukcji jej podporządkowania regułom istniejącego porządku" (tamże: 5). Oto nasza odpowiedź na pytanie o rolę, jaką burżuazja przypisała szkolnictwu wyższemu w epoce III RP. Stało się ono jedną

\footnotetext{
${ }^{9} \mathrm{Na}$ szczęście obecnie zajęcia w szkołach odbywają się przez pięć dni w tygodniu i trwają nieco mniej niż osiem godzin, choć uwzględnienie czasu spędzanego na odrabianiu prac domowych i na „dobrowolnych” zajęciach pozalekcyjnych mogłoby ujawnić, że długość czasu spędzanego na „nauce" jest większa.
} 
z wielu broni - obok bezrobocia, przesunięcia miejsc pracy z przemysłu do usług i z większych zakładów do mniejszych, selektywnego systemu zabezpieczeń socjalnych itd. - mających podzielić i obezwładnić klasę pracująca. W burżuazyjnym arsenale szkolnictwo wyższe stało się broniq ideologicz̨na.

\subsection{Krytyka środowiska akademickiego}

Niektórzy mogliby zaprotestować, żeby spróbować obronić etos uniwersytecki, wskazywać, że o ile na niższych szczeblach oświata faktycznie sprowadza się do nauki milczenia i odtwarzania przekazanych treści, o tyle my - na uniwersytetach - uczymy krytycznego myślenia: samodzielnego formułowania sądów, kwestionowania, dyskutowania. Kształcenie wyższe nie przeciwstawia się jednak wcale niższym szczeblom czy też przeciwstawia się jedynie w takim samym znaczeniu, w jakim według Hegla dojrzewający owoc przeciwstawia się kwiatowi, z którego wyrasta: „,...] przez pojawienie się owocu kwiat zostaje uznany za fałszywe istnienie rośliny i jako jej prawda wchodzi na miejsce kwiatu owoc" (Hegel 1963: 9). Jest ono monstrualnym zwieńczeniem całego systemu edukacji publicznej, zrodzonym przez szkolne Drzewo Poznania Dobra i Zła, trującym owocem, który musiało przełknąc tak wielu Adamów i tak wiele Ew.

Najlepszym na to dowodem jest, że wszystkie sprzeczności tego systemu kulminują się na ostatnim szczeblu kształcenia, tj. na studiach doktoranckich. Rzekome „dyskusje” i „krytyka” na wyższych uczelniach kieruja się taką samą logika jak odpytywanie uczniów w szkołach podstawowych i średnich. Otóż należy przede wszystkim okazać szacunek profesorowi, a następnie powiedzieć to, co nauczyciel chce usłyszeć. Jakiekolwiek zaznaczenie niezależności, czyli próby rzeczywistego zrozumienia przerabianego materiału, i okazanie rzeczywistej kreatywności zostanie natychmiast wytępione. Zajęcia uniwersyteckie oparte są na tych samych zasadach, co inne hierarchicznie zorganizowane, kapitalistyczne instytucje - rolę szefa spełnia prowadzący zajęcia, a zadaniem studentów jest rywalizacja o jego względy. Odpowiada to klasycznemu opisowi alienacji z Releopisów filozoficzno-ekonomicznych Marksa (1962b: 546-560). Studenci sa oddzieleni od siebie nawzajem, gdyż nie są sami dla siebie punktem odniesienia, lecz jest nim profesor, którego łaskę muszą sobie zaskarbić, są więc rywalami. Są też oddzieleni od produktu swojej pracy, gdyż ma on odpowiadać wymogom systemu uniwersyteckiego reprezentowanego przez profesora, a nie zaspokajać autonomicznie określone potrzeby studentów. Wreszcie, są oddzieleni od ludzkiej istoty gatunkowej, którą według młodego Marksa, będącego 
pod heglowskim wpływem, jest wolność, gdyż stosunki uniwersyteckie oparte na arbitralnej władzy człowieka nad człowiekiem są tej wolności jaskrawą negacją ${ }^{10}$.

Droga do emancypacji zawiera w sobie moment krytyki i swobodnej dyskusji - mamy przed sobą pewien cel (wyzwolenie) i zastanawiamy się wspólnie, jak go osiąnąć. Jednakże, akademickie „dyskusje” nie maja z tym nic wspólnego, nawet jeśli, jak na wydziałach nauk społecznych, zahaczaja o kwestie zmian społecznych, to w rzeczywistości nie zakładaja żadnego dążenia do jakiejkolwiek zmiany. Jak wiadomo, znaczone nie jest sztywno przypisane do znaczącego i w kontekście akademickim niezależnie od tematu każde słowo w dyskusji oznacza tylko jedno: ,jestem pilny, jestem grzeczny, naprawdę mi zależy, chcę dostać dobry stopień, jestem lepszy od reszty, och panie profesorze!". Nic zatem dziwnego, że podobnie jak na wcześniejszych etapach kształcenia osoby inteligentne i posiadajace poczucie godności osobistej nie uczestniczą w tego rodzaju odrażającej grze lizusów, bufonów i kujonów ${ }^{11}$.

Trzeba powiedzieć, że środowisko akademickie podjęło się roli „moralnej policji”'12, przypisanej jej w latach 90. przez burżuazję z niezwykłą ochota. Znikły obecne na uniwersytetach resztki kultury opozycyjnej lat 80., a wraz z nią zamarła także niezależna kultura studencka. Żaden z wielkich problemów III RP nie został konsekwentnie podjęty przez akademików, nie mówiąc już o tym, by włączyli się w jego rozwiązywanie: ani bezrobocie, ani atak na wieś, w odpowiedzi na który powstała „Samoobrona”, ani prywatyzacja zakładów pracy, która zostawiła pracowników na lodzie, ani reprywatyzacja gruntów miejskich polegająca na grabieży przez biznes majątku publicznego. Cztery antyspołeczne ciosy zadane przez burżuazję społeczeństwu, czyli „reformy” Jerzego Buzka: oświatowa, emerytalna, administracyjna i zdrowotna, nie doczekały się szerokiej krytyki, a wręcz zostały przyjęte $z$ entuzjazmem ${ }^{13}$. Powstała sprawna, powiększająca się coraz bardziej maszyna ucząca konformizmu, karierowiczostwa i cynizmu, zapewniająca jednak wiele okazji do zarobku i prestiż jej funkcjonariuszom.

\footnotetext{
${ }^{10}$ Harry Cleaver w tekście Praca w sqkole i walka przeciwnko pracy w sælkole (2011a) zastosował kategorię alienacji do analizy rzeczywistości uniwersyteckiej.

${ }^{11}$ Odnośnie do krytyki edukacji, zob. klasyczną pracę Odszkolní spoteczeństwo Ivana Illicha (2010), Nowa Summerbill Alexandra Sutherlanda Neilla (2000) czy prace Hubertusa von Schoenebecka (2007, 2008).

${ }_{12}$ Określenie z przywoływanego już tekstu Mariarosy Dalla Costy i Selmy James (1972: 51).

${ }_{13}$ Mowa tutaj oczywiście o ogólnej tendencji, co nie wyklucza tego, że jednostki zajmowały inne stanowisko. Najszerszą krytykę reformy emerytalnej przeprowadziła prof. Leokadia Oręziak w książce OFE. Katastrofa prywatyzacji emerytur w Polsce. Warto jednak zauważyć, że praca ta została wydana dopiero w 2014 roku, gdy klimat na uczelniach już zaczynał się zmieniać.
} 
Wydaje się jednak, że klasa rządząca padła ofiarą własnego sukcesu. Potężna machina uniwersytecka doskonale sprawdziła się w czasach wysokiego bezrobocia, czyli praktycznie od początku transformacji, aż do 2013, od którego to roku rozpoczyna się trend spadkowy. Wielomilionowa migracja proletariuszy oraz wstrzymywanie się przed posiadaniem dzieci przez rzeszę polskich kobiet hamujących w ten sposób reprodukcję rezerwowej armii pracy doprowadziły do radykalnego spadku bezrobocia ${ }^{14}$. Spadło ono do poziomu nienotowanego od początku transformacji (patrz Aneks, Wykres 3). Od 2013 roku, gdy bezrobocie zaczęło spadać i zmieniła się sytuacja społeczna, zmieniły się także priorytety burżuazji. Problemem nie stało się już ideologiczne urobienie, rozbicie i znalezienie zajęcia proletariatowi, lecz skuteczne włączenie go w polski rynek pracy. Narzucenie masowego bezrobocia spełniło swoje zadanie - spacyfikowało na dekady ruch pracowniczy, lecz środek ten się wyczerpał. Z punktu widzenia burżuazji pracowników jest zbyt mało, by pozwolić tak wielu z nich na wieloletnie studia. Propaganda sukcesu mówiąca o „rynku pracownika” odnosi się właśnie do tej sytuacji społecznej. Niskie bezrobocie rzeczywiście wzmacnia siłę pracowniczą i umożliwia podjęcie walki, na co jednym z dowodów sa protesty budżetówki z lat 2018-2019 (cykl wystąpień: policja, nauczyciele, pracownicy sądów $\left.{ }^{15}\right)$.

W tym momencie można podejrzewać, że klasa rządząca ucieknie się do sprawdzonego sposobu, który pomógł jej rozwiązać problemy z niezdyscyplinowanym społeczeństwem na początku transformacji ustrojowej, czyli ponownie podniesie poziom bezrobocia. Jednym ze sposobów na to jest ograniczenie inkluzywności szkół wyższych: utrudnienie dostępu do kształcenia, a zarazem redukcja kadry akademickiej. Wydaje się, że to właśnie konieczność bezpośredniego wyzysku studentów na rynku pracy stoi za próbami reformy szkolnictwa wyższego podjętymi przez Barbarę Kudrycką i Jarosława Gowina, które zreszta pozostają w swoich ogólnych założeniach spójne $z$ reformą edukacji na niższych szczeblach kształcenia

\footnotetext{
${ }_{14}$ Wiązanie poziomu bezrobocia z liczbą ludności niekoniecznie oznacza rehabilitację jakiejś wersji maltuzjanizmu, oznacza natomiast uwzględnienie faktu, że jeśli praca reprodukcyjna, czyli praca polegająca m.in. na rodzeniu i wychowywaniu kolejnych pokoleń pracowników, nie zostanie wykonana, to burżuazja nie będzie miała kogo wyzyskiwać. Oprócz przywoływanej pracy Dalla Costy i James (1972) zob. także zbiór tekstów Silvii Federici (2012) oraz Selmy James (James, Lopez, Rediker 2012).

${ }^{15}$ Policjanci jako tacy są z pewnością bardzo niejednoznaczną kategorią pracowników - z jednej strony to pracownicy najemni, z drugiej jednak wykorzystywani są przez władzę właśnie do tłumienia protestów społecznych i chronienia własności. W tym kontekście jednak istotne jest jedynie to, że rozpoczęli protest polegający na braniu zwolnień lekarskich (tzw. psia grypa), podchwycony przez innych pracowników.
} 
ograniczającą dostępność do liceów ogólnokształcących i zachęcającą młodzież do wybierania szkół zawodowych. Pewne znaczenie, oprócz ograniczenia liczby studentów, ma też zapewne ograniczenie w szkolnictwie wyższym płatnego zatrudnienia jako takiego. Zarówno liczba nauczycieli akademickich, jak i ogólna liczba pracowników zatrudnionych w szkolnictwie wyższym rosła nieustannie od początku lat 90., gdy tych pierwszych było 60 000, do $100000 \mathrm{w}$ latach 2006/2007'․ Do dziś utrzymuje się ona na zbliżonym, choć nieco mniejszym, poziomie (patrz Aneks Wykres 4) ${ }^{17}$, a wiele szkół wyższych jest znaczącymi pracodawcami w skali regionów ${ }^{18}$.

Tutaj dotykamy drugiego wymiaru „reformy uniwersytetów”, a zarazem kolejnej analogii między fabrykami i uniwersytetami. Te pierwsze po roku 1990 przeszły „restrukturyzacje”, tj. ich załogi zostały zdziesiątkowane, a pozostałym pracownikom narzucona ścisłą kontrolę. Pozbawiono ich autonomii, a zarazem zróżnicowano wynagrodzenia, co spowodowało uprzywilejowanie niektórych kategorii pracowników wykwalifikowanych ${ }^{19}$. Wydaje się, że kolejne rządy planują podobny scenariusz dla szkół wyższych, a nawet że jest on już częściowo realizowany. Świadczą o tym zarówno dane ilościowe wskazujące, że od roku 2012 liczba akademików zmniejszyła się o ponad osiem tysięcy, jak i niektóre posunięcia władz, np. kierunek reformy studiów doktoranckich przeprowadzanej przez Jarosława Gowi-

${ }^{16}$ Do danych dotyczących akademików należy jednak podchodzić z pewną ostrożnością, gdyż: „zdecydowana większość danych dotyczących liczby nauczycieli akademickich jest obarczona dużym marginesem błędu. Istnieja pewne rozbieżności w publikowanych informacjach, m.in. liczba nauczycieli dydaktycznych publikowana przez GUS różni się zarówno od informacji zawartych w danych kadrowych MNiSW, jak i danych raportowanych przez same uczelnie" (Raczyńska 2013: 229). Nawet w danych publikowanych wyłącznie przez GUS w kolejnych latach natknęliśmy się na rozbieżności, np. „Mały Rocznik Statystyczny” z 1991 r. podaje, że nauczycieli akademickich w roku szkolnym 1990/1991 było 62,1 tys. (GUS 1991: 128), a „Mały Rocznik Statystyczny” z 1995 r., że było ich w tym roku szkolnym 64,5 tys. (GUS 1995: 153). W kolejnych latach również pojawiły się tego typu rozbieżności, niemniej jednak nie są one duże, a kierunek zmian jest ten sam we wszystkich źródłach.

${ }^{17}$ Jak powszechnie wiadomo, wzrost liczby nauczycieli akademickich nie dorównywał jednak wzrostowi liczby studentów, co musiało się przełożyć na jakość i komfort pracy na uczelniach. W roku 1990 studentów było około 400 000, a nauczycieli akademickich w przybliżeniu 60 000, co daje stosunek niecałych siedmiu studentów przypadających na jednego nauczyciela. W momencie największego rozkwitu ilościowego uniwersytetów studentów było 2000 000, a nauczycieli akademickich 100 000, co daje dwudziestu studentów na jednego nauczyciela. Jeżeli zatem przyjąć, że jakość kształcenia jest wprost proporcjonalna do stosunku ilościowego między studentami a wykładowcami, to pogorszyła się ona od roku 1990 trzykrotnie.

${ }^{18} \mathrm{Na}$ przykład Uniwersytet Warszawski informuje na swojej stronie internetowej, że „UW to jeden z największych pracodawców na Mazowszu. Pod względem liczby pracowników wyprzedza większość korporacji znajdujących się w zestawieniu największych firm w Polsce magazynu Forbes" (https://www.uw.edu.pl/uniwersytet/fakty-i-liczby/).

${ }^{19} \mathrm{Na}$ temat przemian w zakładach pracy, w tym degradacji pozycji pracowników niewykwalifikowanych zob. studium zakładów Alima-Gerber przeprowadzone przez Elizabeth Dunn, zwłaszcza rozdziały 3 i 4 (2008: 77-153). 
na. Główna zmiana w tym przypadku polega na zapewnieniu stypendiów wszystkim podejmującym studia III stopnia, co niewątpliwie rozwiąże palący problem stałych dochodów w okresie ich odbywania, w zamian jednak za radykalne ograniczenie liczby miejsc na tych studiach ${ }^{20}$. Dość dokładnie odzwierciedla to los pracowników w zakładach przemysłowych lat 90., gdy większość została zwolniona, ale niektórzy z nich mogli objąć lepiej płatne miejsca pracy. W jednym i drugim przypadku metodę stosowana przez burżuazję można skrótowo określić jako „część wyrzuć, część przekup”21.

Kolejną analogią między rozwojem sytuacji w fabrykach wiedzy a fabrykach industrialnych jest zaostrzenie kontroli, tj. wzrost poziomu wyzysku w stosunku do pracowników, którzy utrzymają zatrudnienie. Takie kwestie jak wzmocnienie władzy rektorów, ściślejsze podporządkowanie uczelni państwu i kapitałowi, a także pogłębiony nadzór nad pracą akademików, konieczność spełniania różnych kryteriów ilościowych, ewaluacje i monitoring były już analizowane w kategoriach Marksowskich jako przejście od formalnej subsumpcji pracy intelektualnej pod kapitał do jej subsumpcji realnej ${ }^{22}$. Pojęcie subsumpcji, czyli podporządkowania, wywodzi się z badań Marksa nad przemianami pracy zachodzącymi w zakładach produkcyjnych wraz z powstaniem kapitalizmu. Uznał on, że w pierwszym okresie kapitał opanowuje warsztat rzemieślniczy niejako z zewnątrz, czyli nie ingeruje w sam proces pracy, lecz przechwytuje jedynie jej produkt. To właśnie jest subsumpcja formalna - sama treść pracy, czyli proces produkcji, zachowuje swoja postać odziedziczona po przeszłości. Pracownik wciąż nad nią panuje, posiada szczególne umiejętności i zachowuje w związku $\mathrm{z}$ tym pewną autonomię. Podporządkowanie realne ingeruje $\mathrm{w}$ sam proces produkcji, zmienia sposób pracy w taki, który odzwierciedla priorytety kapitalistyczne, tj. wywłaszcza pracownika $z$ autonomii i maksymalizuje wyciskaną z niego ilość wartości dodatkowej. Tam, gdzie wcześniej pracownik posługiwał się narzędziami, teraz narzędzia przyjmujące postać maszyny posługują się nim.

${ }^{20}$ Por. Ustawa z dnia 20 lipca 2018 r. Prawo o szkolnictwie wyższym i nauce. Według samego Jarosława Gowina: „,...] liczba nowych doktorantów spadnie w nowym naborze o około 40 proc.” (Tomala 2019).

${ }^{21}$ Jeśli chodzi o doktorantów, to reforma ta współgra zresztą z pewnymi resentymentami wyrażanymi przez część tego środowiska, ubolewającego nad utratą elitarności i ekskluzywności studiów III stopnia i niemającego nic przeciwko temu, aby pozbyć się części swoich zbyt plebejskich kolegów, co samo w sobie stanowi wspaniały przykład bufonady i arogancji typowej dla mentalności szkolnych prymusów.

${ }^{22} \mathrm{Na}$ gruncie polskim zostało to opisane przez Oskara Szwabowskiego w pracy Uniwersytet. Fabryka. Maszyna. Uniwersytet w perspektywie radykalnej (2014) oraz Krystiana Szadkowskiego w książce Uniwersytet jako dobro wspólne (2015, zob. zwłaszcza s. 175-223). Kwestii tej poświęcono również zbiorowa publikację Subsumcje edukacji (Chutorański, Moroz, Szwabowski 2018). 
W lewicowej myśli społecznej od dość dawna istnieje tendencja, by dostrzegać analogiczny proces w stosunku do zawodów, co do których wcześniej nie podejrzewano, że mogą przejść tego rodzaju transformację. Dostrzega się więc rozszerzanie sfery realnej subsumpcji na pracę umysłowa, emocjonalna, komunikatywna, kreatywną, słowem na wszelkie aktywności ludzkie ${ }^{23}$. Ująć to można jako postępującą alienację - w fabryce kapitał panuje nad aktywnością fizyczną robotników, w jego władzy znajdują się ręce wykonujące pracę. Podporządkowanie pracy intelektualnej oznacza, że pod jego panowanie dostaje się również głowa, subsumpcja pracy emocjonalnej to opanowanie serca. Ostatecznie człowiek zostaje wywłaszczony ze wszystkiego, co dla niego drogie. W ten sposób najbardziej intymne emocje i myśli stają się nam obce (łacińskie alienum to właśnie obce, cudze), służą obcym nam celom, służą naszym wrogom. W tryby maszyny akumulującej kapitał dostaje się dusza $\ldots .^{24}$

\subsection{Intelektualista jako pracownik}

Czy proces realnej subsumpcji pracy intelektualnej dokonuje się na uniwersytetach? Tak właśnie sądzimy, jasno wynika to z przyjętych założeń, praktyki i dość oczywistych intencji kolejnych ministrów edukacji. Czy oznacza on koniec intelektualistów w Polsce? Nie, ponieważ intelektualistów w Polsce już dawno nie ma. To, co rozumie się zazwyczaj przez to pojęcie, zakłada dystans w stosunku do każdej władzy, niezależność sądu, próbę intelektualnego reprezentowania interesów szerszych niż prymitywnie rozumiany interes własny, zainteresowania wykraczające poza ciasny krag życia codziennego. Jak ujął to Sartre: „Intelektualista to ktoś, kto wtrąca się w coś, co go nie dotyczy" (Cohen-Solal 1989: 588-589) ${ }^{25}$. Wszystkiego tego intelektualiści wyrzekli się już w latach 90. Dario Fo podobno twierdził, że trudno mu wyobrazić sobie prawicowych intelektualistów. Na polskim przykładzie można potwierdzić, że faktycznie coś takiego nie istnieje: polscy intelektualiści zniknęli $\mathrm{w}$ tym samym momencie, $w$ którym pogodzili sie z.władzq, czyli gdy przeszli na pozycje prawicowe. Realne podporządkowanie uniwersytetów jest już tylko ostatnim gwoździem do trumny, w której

\footnotetext{
${ }^{23}$ Wczesną analizę zmierzająca w tym kierunku prezentuje Harry Braverman w klasycznej pracy Labor and Monopoly Capital. Degradation of Work in Twentieth Century (1974).

${ }^{24}$ Trajektorię tę śledzi m.in. Franco Berardi w pracy zawierającej w tytule metaforę duszy: The Soul at Work. From Alienation to Autonomy (2009a).

25 Taka optymistyczna wizja intelektualistów wciąż jest podtrzymywana, przynajmniej w formie postulatu, np. w figurze ,intelektualisty publicznego” promowanej m.in. przez Michaela Burawoya (2005) czy przez H.A. Giroux w jego wizji „,pedagogiki krytycznej”' (Giroux, Witkowski 2010).
} 
spoczywają ich rozkładające się zwłoki. Nie zamierzamy jednak ronić fałszywych łez nad nieboszczykiem, za którym mało kto tęskni, ponieważ: „Wykształcenie, którego utratę bourgeois opłakuje, jest dla olbrzymiej większości kształceniem do spełniania roli maszyny" (Marks 1949a: 40).

Czym właściwie byli tzw. intelektualiści? Swoje pochodzenie zawdzięczają oni podziałowi zajęć, który zwalniał część populacji z pracy fizycznej, ale jednocześnie obarczał resztę pracujących obowiązkiem jej utrzymania. Najbardziej narzucającym się symbolem tej pozycji społecznej jest kapłan, który poświęca cały swój czas pracy głoszeniu słowa bożego. Od słowa kler „właśnie pochodzi przyjęty w wielu językach pochodzenia neołacińskiego, lub rozwiniętych pod silnym wpływem łaciny kościelnej, zwyczaj określania intelektualisty czy specjalisty słowem klerk"' (Gramsci 1961: 688). Rozbrat między praca intelektualną a fizyczną pozwolił niekiedy osobom oddającym się tej pierwszej posiąść bogatą kulturę, jak w przypadku XIX-wiecznej inteligencji burżuazyjnej posługującej się greką i łaciną oraz często kilkoma współczesnymi językami europejskimi, znającej zarówno klasyczne dzieła starożytności, jak i bieżącą literaturę i sztukę.

Niemniej jednak rozbrat ten rodził równie wiele niekorzystnych konsekwencji. Radykalne oddzielenie intelektualistów od pracy fizycznej prowadziło do postrzegania jako realnego świata idei, w którym inteligencja funkcjonowała, podczas gdy świat materialny był jedynie jego bladym odbiciem. Zrodziło to rzeczywistość postawioną na głowie, czy też raczej mieszcząca się jedynie w głowie, jak w przypadku solipsyzmu Berkeleya. Zrodziło to nie-rzeczywistą wizję rzeczywistości, której krytyce poświęcił tak wiele miejsca w swoich dziełach Karol Marks, sam wywodzący się $z$ tego środowiska i będący niejako jego archetypową figurą ${ }^{26}$. Co gorsza, oddzielenie to stanowiło wielką przeszkodę w rozwoju ruchu rewolucyjnego, gdyż w sytuacji, gdy produkcja intelektualna była zmonopolizowana w ramach wąskiej kasty, masy - w XIX wieku w dużej mierze niepiśmienne - pozostawały od niej odcięte. XIX-wieczni poligloci otoczeni byli w dużym stopniu niepiśmienną populacją. Utrudniało to zarówno korzystanie ze zdobyczy nauki, jak i samą komunikację między tymi intelektualistami, którzy przyłączyli się do walki proletariatu, a nim samym ${ }^{27}$. Reproduko-

\footnotetext{
${ }_{26}$ Jego krytyka wymierzona była bezpośrednio w Hegla (Przyczynek do krytyki heglowskiej filozofii prawa, 1962c) oraz współczesną Marksowi lewicę heglowską (napisane wraz z Engelsem: Święta rodzina 1979, Ideologia niemiecka 1961).

${ }^{27}$ Choć jej oczywiście nie uniemożliwiało. Karol Marks jest tutaj znów dobrym przykładem. Karykaturalne przedstawienia tej postaci jako gabinetowego rewolucjonisty, który w życiu nie widział żadnego robotnika, nie mają nic wspólnego z prawdą historyczną. Marks miał z robotnikami do czynienia regularnie, a jedna z jego znanych prac pt. Płaca, cena, zyski (1949) powstała jako wynik dyskusji z cieślą Johnem Westonem odbywającej się w ramach I Międzynarodówki.
} 
wało też w ramach samego ruchu hierarchię między jego członkami - tę samą hierarchię, którą zamierzał on obalić. Istnieja poważne argumenty za tym, że represyjna i autorytarna forma, jaka przyjęły w XX wieku reżimy podające się za komunistyczne, od Azji do Europy Wschodniej, wyniknęła z niemożliwości zniszczenia tej hierarchiii ${ }^{28}$. Mylenie idei z rzeczywistością nie jest niewinnym marzycielstwem ani szlachetnym idealizmem, lecz niebezpieczna psychoza, modelowym przykładem alienacji, w której wytwór (w tym przypadku wytwór głowy) - pojęcie, zaczyna rządzić jego twórca, człowiekiem.

Jak wyżej wspomnieliśmy, najlepszym symbolem pozycji społecznej inteligencji jest kapłan, a zjawisko, o którym teraz mówimy, najlepiej rozumieć na wzór ofiary z prawdziwego, żywego człowieka składanego na ołtarzu bogu, czyli pojęciu będącemu tworem kapłana. Tak też postępowali przywódcy partyjni - teoretycy w rodzaju Lenina, którego koncepcja „wnoszenia świadomości” do mas przez „zawodowych rewolucjonistów” dość dokładnie odpowiada relacji kapłana z wiernymi, głoszącego z ambony Dobrą Nowinę ${ }^{29}$. Podobnie było w przypadku Stalina, Mao Tse-tunga czy Kim Ir Sena, poświęcających życie realnie istniejących ludzi w imię abstrakcyjnych ideałów - idealistycznie rozumianego „komunizmu”, „postępu”, „ojczyzny” itp. Tymczasem za owymi wzniosłymi ideałami, tak jak za wszystkimi innymi, kryły się bardzo ziemskie treści, mianowicie relacje władzy między posługującymi się nimi intelektualistami a proletariatem, którego to życie było właśnie poświęcane ${ }^{30}$.

\footnotetext{
${ }^{28}$ Jednym $z$ fascynujących fenomenów w historii idei lewicowych jest to, że autorytarna degeneracja ruchu została przewidziana jeszcze przed jego dojściem do władzy, a jako źródło tej degeneracji wskazywano właśnie władzę intelektualistów w ruchu antysystemowym. W latach 70. XIX wieku Michaił Bakunin w odniesieniu do socjalizmu etatystycznego pisał: „Będzie to panowanie inteligencji naukowej, najbardziej arystokratyczny, despotyczny, arogancki i pogardliwy reżim ze wszystkich. Da to nową klasę, nową hierarchię rzeczywistych i rzekomych naukowców i uczonych, a świat zostanie podzielony na mniejszość, która będzie rządziła w imieniu wiedzy i na ogromną nieuświadomioną większość" (Bakunin 1950). Podobne pozycje zajmował polski radykał Jan Wacław Machajski, którego dzieła zebrane w publikacji Pracownik umystowy i inne pisma (2016) stanowia jedną wielką demaskację inteligencji. Za współczesną kontynuację tego podejścia można uznać pracę Michała Siermińskiego omawiającą rolę lewicowej inteligencji opozycyjnej w konflikcie między partyjną biurokracją a klasą robotniczą w okresie PRL-u (2016).

${ }_{29}$ Odnośnie do idei „wnoszenia świadomości klasowej” przez zawodowych rewolucjonistów do mas niezdolnych wykształcić jej spontanicznie zob. Co robić? Palace zagadnienia nasæego ruchu (1984). W kontekście edukacji warto tutaj także przywołać leninowskie hasło ukute niby motto państwowych systemów kształcenia: „po pierwsze - uczyć się, po drugie - uczyć się, i po trzecie - uczyć się, a następnie kontrolować..." (Lenin 1989: 383).

${ }^{30}$ Bo też właśnie ten rodzaj idealizmu nie jest niczym innym jak idealistycznym wyrazem władzy. Por. z podejściem Gramsciego ze słynnego tekstu o ,intelektualistach organicznych”, który najpierw przypisuje intelektualistom kluczową rolę w ruchu rewolucyjnym („Działalność intelektualisty nowego typu nie może polegać wyłącznie na elokwencji, tym zewnętrznym i chwilowym motorze uczuć i namiętności, ale na aktywnym włączaniu się w życie praktyczne w charakterze bu-
} 
Jednakże rozwój produkcji kapitalistycznej obejmujący noosferę, sferę rozumu, likwidując inteligencję jako uprzywilejowaną kastę, likwiduje zarazem jej władzę nad klasa pracująca, a zatem usuwa wszystkie te niebezpieczeństwa. Z jednej strony, status pracowników umysłowych uległ obniżeniu i zniknęła charakteryzująca ich autonomia, a z drugiej - umiejętności zarezerwowane do niedawna dla wąskiego grona osób rozszerzyły się na większość populacji. Kolejne fazy akumulacji kapitału wiąża się z powstawaniem nowych branż, lecz zmiany te nie ograniczają się po prostu do tego, że część klasy pracującej zostaje zatrudniona w nowych gałęziach gospodarki. Proces pracy zmienia się we wszystkich branżach, a wzory konsumpcji w całym społeczeństwie. Przykładowo, w epoce przemysłowej praca na roli zaczęła się stopniowo wiązać z posługiwaniem się wyrobami przemysłu - traktorami, ciagnikami itp., a społeczeństwo zaczęło korzystać z produktów fabrycznych w życiu codziennym, ubrań, telewizorów, samochodów (Hardt, Negri 2004: 107-115). W epoce kapitalizmu semiotycznego ${ }^{31}$ znaki nasycają również proces produkcji w przemyśle czy rolnictwie (traktory wyposażone w komputery) i pierwszy raz w historii tak ogromna rzesza ludzi posługuje się czynnie pismem, posiada dostęp do ogromnych baz danych i może komunikować się z ludźmi o zbliżonych zainteresowaniach ${ }^{32}$. Pracownicy umysłowi, w tym pracownicy akademiccy, nie posiadaja już żadnego uprzywilejowanego statusu. Są raczej częścią nowej różnorodnej klasy pracującej, podobnie jak inne grupy pracowników najemnych.

\footnotetext{
downiczego, nieustannie przekonywajacego organizatora...”, Gramsci 1961: 691), a następnie zrównuje intelektualistów z partią („Twierdzenie, że wszystkich członków partii politycznej należy uważać za inteligentów, wydaje się na pozór żartem lub karykaturą, ale gdy się nad nim głębiej zastanowić, okazuje się zupełnie słuszne”, Gramsci 1961: 699). Nic więc dziwnego, że operaiści w podsumowaniu doświadczenia Włoskiej Partii Komunistycznej, dla której Gramsci pozostawał najważniejszym teoretykiem, mogli stwierdzić, że tzw. intelektualista organiczny ,jest w praktyce organiczny jedynie w stosunku do machiny partyjnej" (Wright 2002: 17). Jeśli chodzi o zakwestionowanie roli intelektualisty w ruchu rewolucyjnym to zob. poglądy Michela Foucaulta ukształtowane pod wpływem francuskiego Maja '68: „W czasie ostatnich rozruchów intelektualista stwierdził, że nie jest masom do niczego potrzebny, bo te są nie tylko doskonale uświadomione, nie mają złudzeń, ale także posiadają większą wiedzę od samego intelektualisty, a do tego potrafią wyrażać swoje poglądy" (Deleuze, Foucault 2013: 77).

${ }_{31}$ Koncepcje „kapitalizmu semiotycznego” w nawiązaniu do prac Jeana Baudrillarda rozwija Franco Berardi, zob. np. Precarious Rhapsody. Semiocapitalism and the Pathologies of the Post-Alpha Generation (2009b).

32 Dostrzeżenie tego faktu oczywiście nie oznacza rehabilitacji pojęcia „postępu” rozumianego w sensie rozwoju sił wytwórczych - produkcja komputerów wiąże się z zatrważającym zniszczeniem środowiska i nieludzkim wyzyskiem. Na ten temat zob. np. Niewolnicy Apple'a. Wyzysk i opór w chinskich fabrykach Foxconna (Ngai, Huilin, Yuhua, Yuan, Ruckus 2013).
} 


\section{/// Konkluzje}

Skoro zatem reforma kształcenia wyższego posiada ten szczególnie „egalitarny" wymiar, zrównuje akademików z resztą klasy pracującej, to czy powinniśmy patrzeć na nią ze spokojem, czy wręcz powitać z entuzjazmem, jak niektórzy młodzi naukowcy zmęczeni paternalistycznym feudalizmem starych stosunków uniwersyteckich? Nie. Byłoby to równie błędne jak reakcyjna próba zachowania uniwersytetów w obecnym kształcie. Restrukturyzacja fabryk wiedzy, jak staraliśmy się to wykazać, jest tak samo antyspołecznym atakiem na klasę pracująca jak restrukturyzacja fabryk przemysłowych. Jeżeli zostanie przeprowadzona zgodnie z planami burżuazji, to zarówno podwyższy poziom bezrobocia, jak i „znormalizuje” uniwersytety.

Tutaj dochodzimy do jeszcze jednego aspektu sytuacji na uczelniach wyższych. Z jednej strony, jeśli chodzi o pracowników akademickich, to atak na uniwersytety już się rozpoczął. Przestają być one prestiżowymi miejscami pracy, co umożliwia osobom niewywodzącym się z mieszczańskich rodzin zatrudnienie się na nich, a zarazem zmniejsza dystans między nauczycielami a studentami. Z drugiej jednak strony, jeśli chodzi o studentów, to wszystkie zagrywki burżuazji działaja jedynie na krótką metę ${ }^{33}$. Wydaje się, że proletariat przejrzal już wybieg związany z tzw. wyższym wykształceniem. Inaczej mówiąc, studenci wiedzą już, że nie gwarantuje ono awansu klasowego. Przestają więc przywiązywać do niego nadmierne znaczenie, na które zresztą nigdy nie zasługiwało. Przestają okazywać nabożną cześć prowadzącym zajęcia. Przestaje im zależeć na zdobyciu tytułu, na co wskazuje coraz bardziej powszechny wzór zmieniania kierunków studiowania po kilku latach. Kierują się w studiach swoimi zainteresowaniami, a nie wymogami profesorów czy rynku pracy. Ośmielają się nawet zadawać pytania.

Choć należy być w tej kwestii ostrożnym, to być może symptomy, o których wspomniałem, wskazują na to, że część studentów zaczyna traktować studia, które burżuazja stworzyła na potrzebę produkcji posłusznych pracowników, jako sposób na rozwój zainteresowań, odpowiedź na swoje pragnienia i realizację własnych interesów, a nie drogę do integracji ze społeczeństwem kapitalistycznym. Ta część zaprzecza zatem negacji podmiotowości, jaką jest kapitalistyczny uniwersytet. Odpowiada to pojęciu samo-

\footnotetext{
${ }_{33}$ Dlatego też burżuazja musi posługiwać się nieustannymi zmianami, dokonywać przesunięć organizacyjnych, przestrzennych i branżowych. Kwestię tę teoretyzuje Beverly Silver w jednej z ważniejszych wydanych po polsku prac utrzymanych w perspektywie klasowej pt. Globalny proletariat (2009); samo pojęcie „przesunięcia” (fix) wprowadził David Harvey (1989: 189-200).
} 
rozwoju robotniczego ukutemu przez włoskich marksistów na oznaczenie autonomicznych działań klasy pracującej, gdy staje się ona sama dla siebie punktem odniesienia ${ }^{34}$.

W teorii samorozwojowi pracowniczemu towarzyszy „rekompozycja polityczna” i pewne jej oznaki można odnaleźć na uniwersytecie. Powstanie Uniwersytetu Zaangażowanego, który przewodził na Uniwersytecie Warszawskim protestowi określonemu przez „Gazetę Wyborczą” jako „największy protest od czasów PRL-u” (Karpieszuk 2015); działalność ogólnopolskiego Komitetu Kryzysowego Humanistyki Polskiej próbującego zahamować neoliberalne reformy; założenie komisji Inicjatywy Pracowniczej na uniwersytetach; utworzenie Studenckiego Komitetu Antyfaszystowskiego odpierającego faszystowską infiltrację struktur akademickich - te wszystkie działania są wyrazem zmiany klimatu na uczelniach podczas kilku ostatnich lat. Świadczą one o poszerzeniu się przestrzeni wolności w ramach instytucji kształcenia wyższego. Sądzimy, że jednym z celów reformy jest właśnie zniszczenie tej wolności, wyrwanie z korzeniami tej delikatnej rośliny (z punktu widzenia władzy - chwastu), zanim zdąży się ona rozplenić na uniwersyteckim gruncie ${ }^{35}$.

Właśnie te inicjatywy odpowiadają na pytanie: „Co robić?”, w kontekście aktualnej reformy. Zamiast przepełnionego resentymentem schadenfreude płynącego z tego, że akademików niezdolnych wcześniej do solidarności z klasa pracująca spotyka ten sam los, który dotkną ją wcześniej, z antykapitalistycznej perspektywy to zablokowanie reformy, uniemożliwienie cięć i zwolnień jest działaniem, które służy szeroko rozumianej klasie pracujacej i krzyżuje plany burżuazji. Nie znaczy to jednak, że uznajemy sytuacje na uniwersytetach za zadowalająca. Sprzeciw wobec wdrażania reformy nie musi przekładać się na zachowanie status quo, zresztą nikt tego nie postuluje. Nie ma co dalej pudrować rozkładającego się truchła inteligencji, należy porzucić całkowicie tę pretensjonalną tożsamość. Pracownicy akademiccy, którym zależy na „uniwersytecie jako dobru wspólnym”, są zbuntowaną

\footnotetext{
${ }_{34}$ Włoskie Autovalorizzazione - zostało utworzone w opozycji do pojęcia samopomnażania kapitału - wywodzącego się z „klasycznego” marksizmu. Tłumaczenie terminów związanych z tą kwestią dostarcza wielu problemów. Tutaj zdecydowaliśmy się podążać za wyborami tłumacza książki Harry’ego Cleavera Polityczne czytanie „Kapitatu” (Cleaver 2011b). Na temat pojęcia samowaloryzacji zob. także Cleaver 1992.

35 „Rekompozycja polityczna” znacznie bardziej widoczna jest na niższych stopniach kształcenia. Koronnym dowodem jest tutaj pierwszy od 1993 roku strajk generalny w oświacie, który odbył się w 2019 roku, ale również ożywienie się środowisk uczniowskich, powstanie Strajku Uczniowskiego, początkowo wspierającego protest nauczycieli, a obecnie protestującego przeciwko brakowi miejsc w szkołach średnich.
} 
grupą pracowników, a nie żadnymi ,intelektualistami”36, i powinni skupiać się na rozszerzeniu tego buntu. To właśnie oznacza rekompozycję polityczną. Jej dokończenie wymaga przejścia do ataku, otworzenia nowych frontów walki z ministerstwem, eskalacji żqadań, a zarazem próby wejścia w relację i zjednoczenie $z$ innymi grupami pracowników ${ }^{37}$. Porównać można to do wymiany ciosów podczas pojedynku bokserskiego - cios przeciwnika (reforma), blok (zablokowanie reformy), nasz atak (silniejszy).

Mobilizacja polityczna na uniwersytecie wciąż jednak nie wyszła poza mniejszościowa grupę aktywistów, a akcje przez nia prowadzone zdają się raczej odpowiadać na ataki burżuazji, niż inicjować nowe konflikty w niespodziewanych przez nią miejscach ${ }^{38}$. Wciąż nie znaleźliśmy kwestii i haseł, które poruszyłyby większość studentów, ani sposobów, którymi moglibyśmy do nich dotrzeć. Zajęcia wciąż odbywają się w sposób odtwarzający kapitalistyczne relacje społeczne, a społeczeństwo nie ma praktycznie żadnych korzyści z funkcjonowania szkolnictwa wyższego. Na wszystkie te kwestie musimy odpowiedzieć, zmieniając zarówno przedmiot nauki, jak i nauczającego, nauczanego oraz sposób nauczania, słowem - cała naukę. W odniesieniu do nauczanych powinniśmy, być może, zgodnie z tradycją operaistyczną podjąć współbadanie środowiska studenckiego, ażeby dotrzeć do pragnień, potrzeb i obszarów konfliktu, w które można interweniować. W odniesieniu do nauczających musimy znaleźć inny sposób odnoszenia się do studentów i do siebie nawzajem, który wolny będzie od kapitalistycznej rywalizacji i hierarchii. Musimy odkryć sposoby przekazywania wiedzy, które ograniczą rolę ocen i egzaminów. Wreszcie, musimy przekierować produkcję intelektualną tak, by odpowiadała na potrzeby pracowników, a nie kapitalistów, czyli tworzyć wiedzę - zarówno humanistyczną, jak i typowo techniczną - użyteczną w walce o wzrost

\footnotetext{
${ }^{36}$ Wydaje się, że wciąż jednak istnieją wśród nich tacy, którzy nie zdali sobie sprawy z własnej śmierci. Jak w filmach o duchach, które nie wiedzą o własnym zgonie, kontynuują oni swój inteligencki żywot, robiąc to, co wcześniej. Podkreślają swoją wyższość, choć są już tylko irytujący, prowadzą niekończące się dyskusje, z których nic nie wynika, organizują do niczego nieprowadzące konferencje, debaty i seminaria, redagują czasopisma i piszą artykuły, których nikt nie czyta. Od dawna już nie ma w tych praktykach żadnej żywej treści. Opuścił je Duch Świata, a objął w posiadanie Duch Święty. Są one tylko pustym rytuałem.

${ }^{37}$ Zgodnie z definicja przytoczona przez Jarosława Urbańskiego rekompozycja zawsze zakłada „usuwanie kapitalistycznych podziałów, tworzenie nowych powiązań między różnymi sektorami klasy oraz poszerzenie tego, co uznajemy za klasę robotniczą" (2014: 37).

${ }^{38} \mathrm{~W}$ nomenklaturze Beverly Silver nie są to więc protesty typu marksowskiego, lecz raczej polyainowskiego: „Przez protesty tego drugiego typu rozumiemy opór będący reakcją na rozprzestrzenianie się globalnego samoregulującego rynku; dotyczy to zwłaszcza klas pracujących, które znikaja na skutek oddziaływania globalnych przemian” (Silver 2009: 39-44).
} 
wynagrodzeń, ograniczenie czasu pracy i podniesienie jakości życia. Musimy więc stworzyć wiedzę użyteczną w walce klasowej ${ }^{39}$.

Istnieją obecnie wszystkie warunki, by faktycznie podjąć takie działania na uniwersytetach. Ustawa 2.0 została wprawdzie uchwalona, ale nie została jeszcze wdrożona i wytworzyła jedynie chaos, który umożliwia działanie. Stare struktury się chwieją, a nowe jeszcze się nie skonsolidowały i właśnie dzięki temu otworzyła się przestrzeń na autonomiczne akcje. Czasu nie ma jednak wiele. Śpieszmy się zatem, by zdążyć przed mrokiem zwolnień, represji i narzuconego konformizmu, które zaraz się zaczną. Jutro będzie za późno. Wszystko wskazuje na to, że jeśli zmarnujemy tę okazję, dojdzie do umocnienia autorytarnych struktur, a pochodzący spoza burżuazji studenci i nie chcący się podporządkować pracownicy znajdą się poza uniwersytetem ${ }^{40}$, co zagwarantuje, że przez kolejne ćwierć wieku na uczelniach wyższych panować będzie cmentarny spokój. Rozum znów uśnie i obudzą się demony. Dziś jednak wciąż możemy pokrzyżować ich plany i trudno byłoby wymarzyć sobie lepszy moment. Czarne Pantery zwykły mawiać w takich sytuacjach: Seize the time!

\footnotetext{
${ }^{39}$ Jeśli chodzi o badania utrzymane w tradycji operaistycznej, zob. artykuły zebrane w: „Viewpoint Magazine”, nr 3, pt. Workers' Inquiry, zawierającym zarówno „klasyczne” prace z okresu powojennego, jak i współczesne nawiązania (2013). Odnośnie do tych ostatnich zob. także: Shukaitis, Graeber i Biddle (2007) oraz Król (2007). Kontekst powstania idei współbadania na tle historii ruchu operaistycznego, zob. Wright 2002.

${ }^{40}$ Sa już pierwsze zwiastuny tego procesu - na przykład zwolnienie Ewy Majewskiej z UW. Więcej o sprawie zob. Woś 2019.
} 


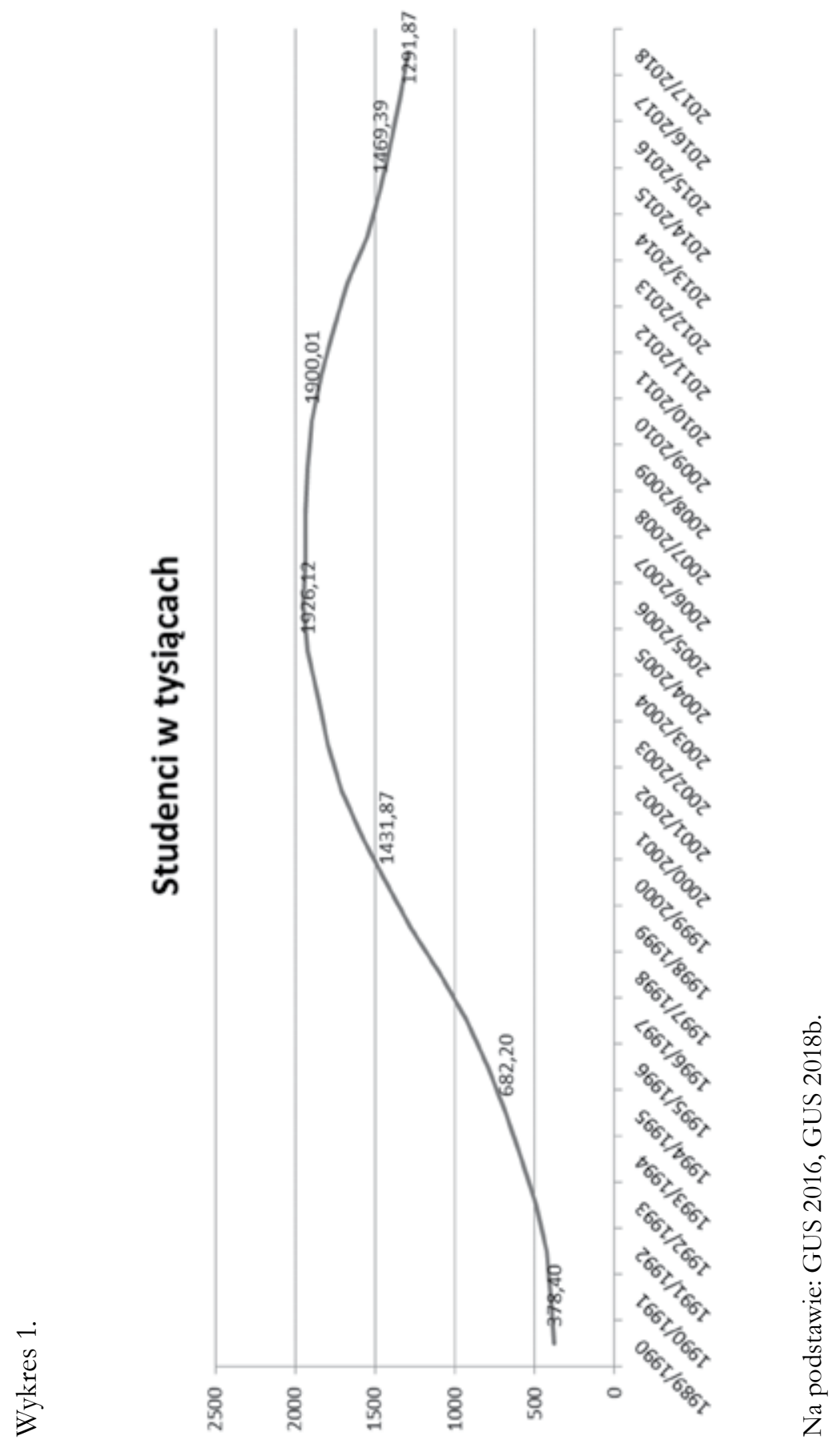

/ 224 STANRZECZY 1[16]/2019 


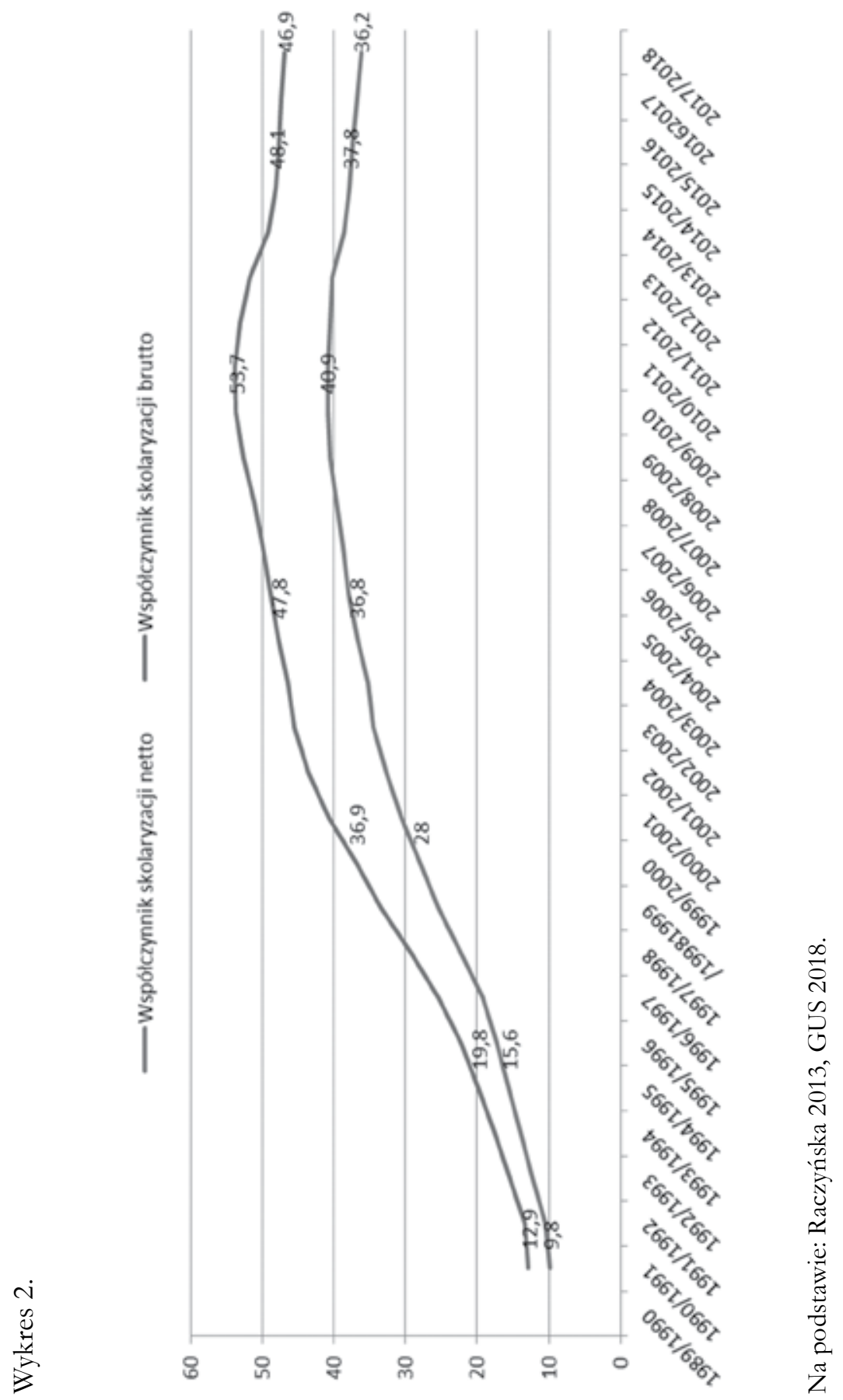

STANRZECZY 1[16]/2019 ～/ 225 


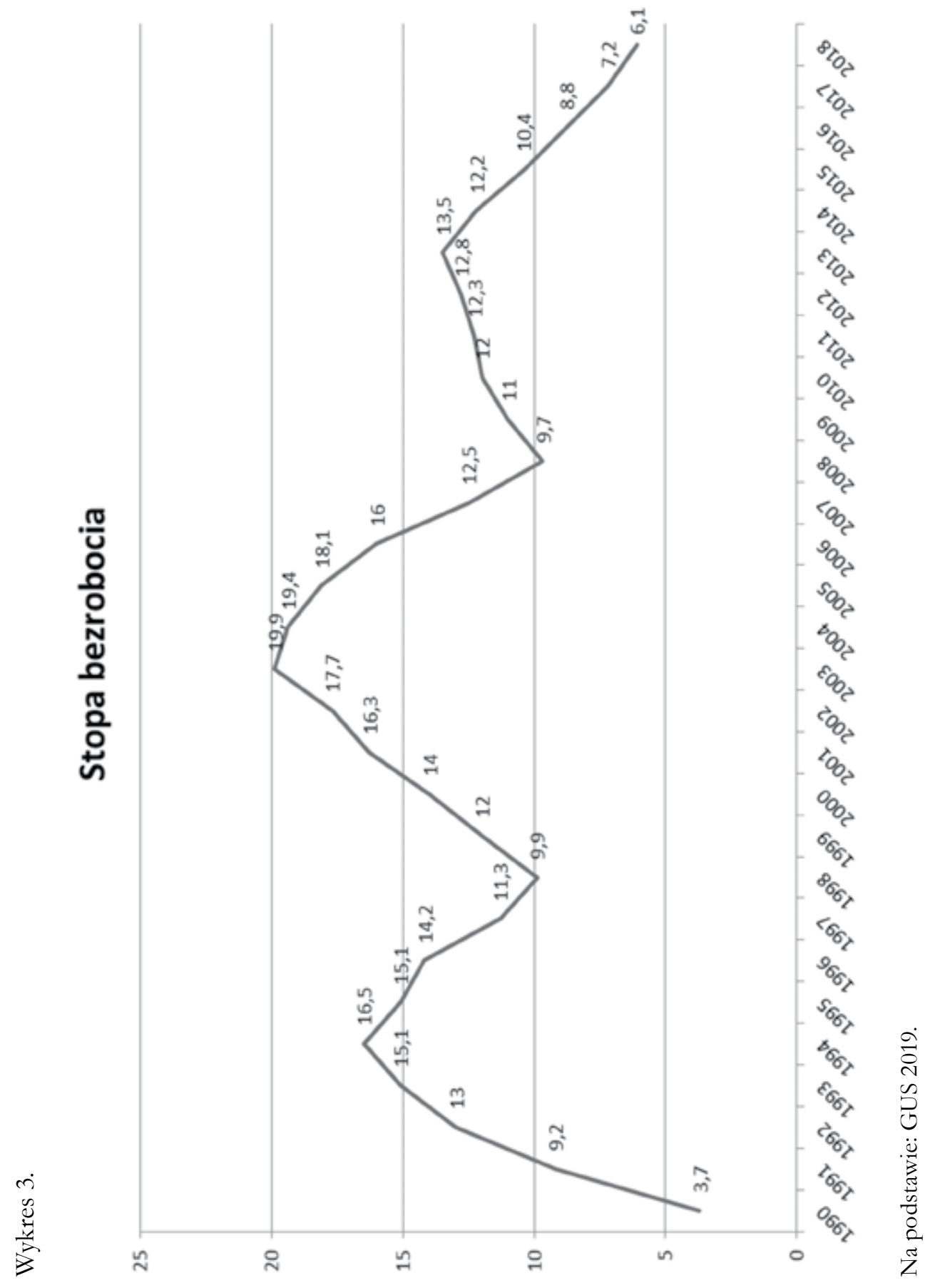

/ 226 STANRZECZY 1[16]/2019 


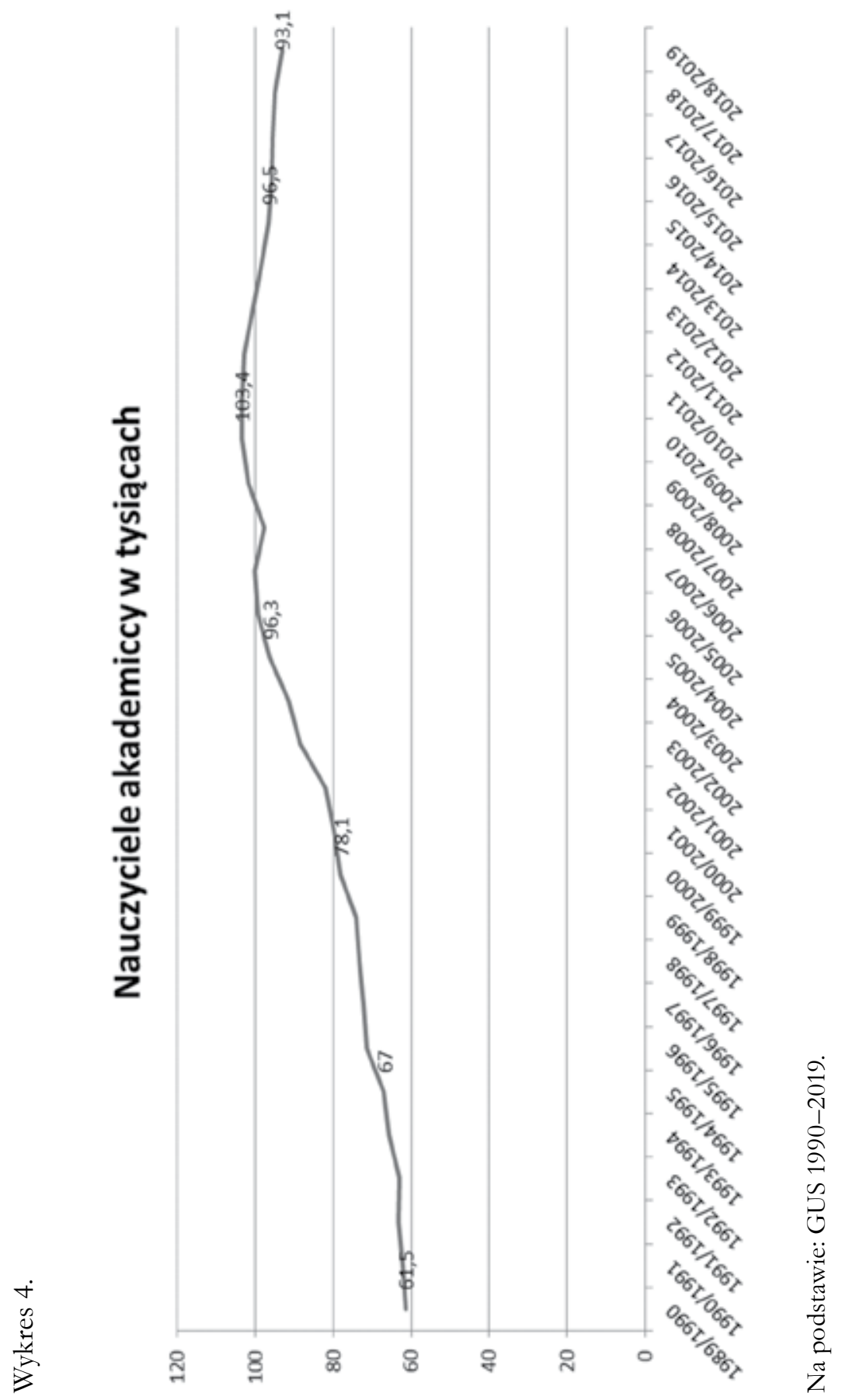

STANRZECZY 1[16]/2019 ～/ 227 
Bibliografia:

/// Althusser L. 2006. Ideologie i aparaty ideologiczne państwa. Wskazónki do badań, tłum. A. Staroń. http://marksizm.edu.pl/wydawnictwa/wspolczesna-mysl-marksistowska/louis-althusser/ideologie-i-aparaty-ideologiczne-panstwa/; dostęp: 18.07.2019.

/// Amair J. i in. 2018. A Socialisme ou Barbarie Anthology: Autonomy, Critique, and Revolution in the Age of Bureaucratic Capitalism, Eris.

/// Bakunin M. 1950. Państwo i marksiżm, tłum. A. Pluta. http://www.bakunin.pl/pis_marksizm.htm; dostęp: 18.07.2019.

/// Berardi F. 2009a. The Soul at Work. From Alienation to Autonomy, thum. F. Cadel, G. Mecchia, Semiotext(e).

/// Berardi F. 2009b. Precarious Rhapsody. Semiocapitalism and the Pathologies of the Post-Alpha Generation, tłum. A. Bove, E. Empson, M. Goddard, G. Mecchia, A. Schintu, S. Wright, Minor Compositions.

/// Braverman H. 1974. Labor and Monopoly Capital: The Degradation of Work in the Twentieth Century, Monthly Review Press.

/// Burawoy M. 2005. 2004 American Sociological Association Presidential Address: For Public Sociology, „American Sociological Review”, vol. 70, nr 1, s. 4-28.

/// Chutorański M., Moroz J., Szwabowski O. 2018. Subsumcje edukacji, Wydawnictwo Naukowe Katedra.

/// Cleaver H. 1992. The Inversion of Class Perspective in Marxian Theory: From Valorization to Self-Valorization, [w:] Open Marxism, red. W. Bonefeld, R. Gunn, K. Psychopedis, Pluto Press, s. 106-144.

/// Cleaver H. 2011a. Praca w szkole i walka przecinkeo pracy w szkole, thum. Wila, „Przegląd Anarchistyczny”, nr 13, s. 29-68.

/// Cleaver H. 2011b. Polityczne czytanie „Kapitału”, tłum. I. Czyż, Bractwo Trojka.

/// Cohen-Solal A. 1989. Sartre, Gallimard.

/// Dalla Costa M., James S. 1972. The Power of Women and the Subversion of the Community, Falling Wall Press. 
/// Debord G. 2006. Spoleczeństwo spektaklu oraz Roz̧ważania o społeczeństwie spektaklu, tłum. M. Kwaterko, Państwowy Instytut Wydawniczy.

/// Deleuze G., Foucault M. 2012. Intelektualisci a władza. Rozmowa Michela Foucault z Gilles'em Deleure'em, tłum. S. Magala, M. Roszkowska, „Format P”, nr 8, s.75-88.

/// Dunn E. 2008. Prywatyzujac Polske. O bobofrutach, wielkim biznesie i restrukturyzacji pracy, tłum. P. Sadura, Wydawnictwo Krytyki Politycznej.

/// Federici S. 2012. Revolution at Point Zero: Housework, Reproduction, and Feminist Struggle, PM Press.

/// Foucault M. 2011. Nadzorować i karać. Narodziny mięzienia, tłum. T. Komendant, Wydawnictwo Aletheia.

/// Gdula M. 2018. Nowy autorytaryzm, Wydawnictwo Krytyki Politycznej.

/// Gieczys-Jurszo A. 2019. Strajk Uçniowski, „Alfabet Buntu Archiwum Osiatyńskiego". https://archiwumosiatynskiego.pl/alfabet-buntu/strajk-uczniowski/; dostęp: 06.08.2019.

/// Giroux H.A., Witkowski L. 2010. Edukacja i sfera publiczna, tłum. M. Jaworska-Witkowska, E. Kiszkurno-Koziej, P. Kwieciński, A. Nalaskowski, L. Witkowski, P. Zamojski, Oficyna Wydawnicza „Impuls”.

/// Główny Urząd Statystyczny. 1990-2019. Mały Rocznik Statystyczny 1990-2019, Zakład Wydawnictw Statystycznych.

/// Główny Urząd Statystyczny. 2016. Szkoly wyższe i ich finanse w 2015 r., Zakład Wydawnictw Statystycznych.

/// Główny Urząd Statystyczny. 2018a. Rocznik Statystyczny Rz̧eczypospolitej Polskiej 2018, Zakład Wydawnictw Statystycznych.

/// Główny Urząd Statystyczny. 2018b. Szkooky wyższe i ich finanse w 2017 r., Zakład Wydawnictw Statystycznych.

/// Główny Urząd Statystyczny. 2019 Stopa bezrobocia rejestrowanego w latach 1990-2019. https://stat.gov.pl/obszary-tematyczne/rynek-pracy/bezrobocie-rejestrowane/stopa-bezrobocia-rejestrowanego-w-latach-1990-2019,4,1.html; dostęp: 26.07.2019.

/// Gramsci A. 1961. Intelektualisci i organizowanie kultury, tłum. B. Sieroszewska, [w:] tegoż, Pisma wybrane, t. 1, Książka i Wiedza, s. 685-736. 
/// Hardt M., Negri A. 2004. Multitude. War and Democracy in the Age of Empire, The Penguin Press.

/// Harvey D. 1989. The Condition of Postmodernity. An Enquiry into the Origins of Cultural Change, Blackwell Publishers.

/// Hegel G.W.F. 2002. Fenomenologia ducha, tłum. F.Ś. Nowicki, Wydawnictwo Aletheia.

/// Illich I. 2010. Odsžolnić społeczeństwo, tłum. Ł. Mojsak, Fundacja Nowej Kultury Bęc Zmiana.

/// James S., Lopez N., Rediker M. 2012. Sex, Race and Class: The Perspective of Winning. A Selection of Writings 1952-2011, PM Press.

/// Karpieszuk W. 2015. Na UW najwiekszy protest od PRL-u. „Uniwersytet to my”, „Gazeta Wyborcza”. http://warszawa.wyborcza.pl/warszawa/1,34862, 17886527,Na_UW_najwiekszy_protest_od_PRL_u___Uniwersytet_ to.html; dostęp: 06.08.2019.

/// Kowalik T. 2009. www.polskatransformacja.pl., Warszawskie Wydawnictwo Literackie Muza SA.

/// Król K., red. 2007. Autonomia robotnicæa, Wydawnictwo Poznańskiej Biblioteki Anarchistycznej.

/// Kuroń J., Modzelewski K. 2009. List otwarty do partii, [w:] J. Kuroń, Dojrzewanie. Pisma polityczne 1964-1968, Wydawnictwo Krytyki Politycznej, s. 5-89.

/// Lee C.G., Chaulieu P., Johnson J.R. 1958. Facing Reality: The New Society... Where to Look for It, How to Bring It Closer, A Statement for Our Time, Correspondence Publishing Company.

/// Lenin W. 1984. Co robić? Palace zagadnienia naszego ruchu, thum. zbiorowe, [w:] tegoż, Dzieła wszystkie, t. 5, Książka i Wiedza.

/// Lenin W. 1989. Lepiej mniej, ale lepiej, tłum. zbiorowe, [w:] tegoż, Drieła wszystkie, t. 45, Książka i Wiedza, s. 380-395.

/// Machajski J.W. 2016. Pracownik umystowy i inne pisma, Wydawnictwa Uniwersytetu Warszawskiego.

/// Magala S. [Starski S.] 2012. Walka klas w berklasowej Polsce, tłum. J.F. Dąbrowski, Europejskie Centrum Solidarności. 
/// Marks K. 1949. Płaca, cena i zysk, tłum. nieznany, [w:] K. Marks, F. Engels, Drieła wybrane, t. 1, Wydawnictwo „Książka i Wiedza”, s. 372-419.

/// Marks K. 1962a. Przyczynek do krytyki heglowskiej filozofii prawa. Wstep, tłum. L. Kołakowski, [w:] K. Marks, F. Engels, Drieła, t. 1, Wydawnictwo „Książka i Wiedza”, s. 457-473.

/// Marks K. 1962b. Rekopisy ekonomicæno-filozoficzne z.1844 r., tłum. K. Jażdżewski, T. Zabłudowski, [w:] K. Marks, F. Engels, Drieła, t. 1, Wydawnictwo „Książka i Wiedza”, s. 497-639.

/// Marks K. 1962c. Przyczynek do krytyki heglowskiej filozofii prawa, thum. T. Zabłudowski, [w:] K. Marks, F. Engels, Drieła, t. 1, Wydawnictwo „Książka i Wiedza”, s. 243-407.

/// Marks K., Engels F. 1949. Manifest komunistyczny, tłum. nieznany, [w:] tychże, Drieła wybrane, t. 1, Wydawnictwo „Książka i Wiedza”, s. 14-55.

/// Marks K., Engels F. 1961. Ideologia niemiecka. Krytyka najnowszej filozofii niemieckiej w osobach jej przedstawicieli - Fenerbacha, B. Banera i Stirnera, tudzież niemieckiego socjaliżmu w osobach różnych jego proroków, tłum. K. Bleszyński, S. Filmus, [w:] tychże, Drieła, t. 3, Wydawnictwo „Książka i Wiedza”, s. 9-619.

/// Marks K., Engels F. 1972. Święta rodzina, czyli Krytyka krytycznej krytyki. Przeciwke Brunonowi Bauerowi i spótce, tłum. T. Kroński, S. Filmus, [w:] tychże, Drieła, t. 2, Wydawnictwo „Książka i Wiedza”, s. 3-265.

/// Neill A.S. 2000. Nowa Summerbill, tłum. M. Duch, Zysk i S-ka.

/// Ngai P., Huilin L., Yuhua G., Yuan S., Ruckus R., red. 2013. Niewolnicy Apple'a. Wyzysk i opór w chinskich fabrykach Foxconna, tłum. M. Walulik, Oficyna Wydawnicza Bractwa „Trojka”.

/// Nietzsche F. 1912. Jutrzenka. Myśli o pržesadach moralnych, tłum. S. Wyrzykowski, Nakład Jakóba Mortkowicza.

/// Oręziak L. 2014. OFE. Katastrofa prywatyzacji emerytur w Polsce, Instytut Wydawniczy Książka i Prasa.

/// Raczyńska M. 2013. Od elitarności do masowości. Stan sækolnictwa wyższego w Polsce po transformacji ustrojowej z 1989 r., „Poliarchia”, nr 1, s. 217-244.

/// Schoenebeck H. 2007. Antypedagogika. Być i wspierać zamiast uychowania, tłum. N. Szymańska, Jacek Santorski \& Co. 
/// Schoenebeck H. 2008. Wolność od wychowania, tłum. G. Słowiński, Oficyna Wydawnicza Impuls.

/// Seale B. 1970. Seize the Time: The Story of the Black Panther Party and Huey P. Newton, Random House.

/// Shukaitis S., Graeber D., Bidlle E., red. 2007. Constituent Imagination: Militant Investigations, Collective Theorization, AK Press.

/// Siermiński M. 2016. Dekada pržetomu. Polska lewica opozycyjna 1968-1980. Od demokracji robotniczej do narodowego paternalizmu, Książka i Prasa.

/// Silver B.J. 2009. Globalny proletariat. Ruchy pracownicze i globalizacja po 1870 r., tłum. M. Starnawski, Instytut Wydawniczy Książka i Prasa.

/// Szadkowski K. 2015. Uniwersytet jako dobro wspólne. Podstawy krytycznych badań nad szkolnictwem wy:ssym, Wydawnictwo Naukowe PWN.

/// Szwabowski O. 2014. Uniwersytet. Fabryka. Maszyna. Uniwersytet w perspektywie radykalnej, Instytut Wydawniczy Książka i Prasa.

/// Tomala L. 2019. Gowin: licz̧ba nowych doktorantów spadnie, PAP - Nauka w Polsce. http://naukawpolsce.pap.pl/aktualnosci/news $\% 2 \mathrm{C} 77557 \% 2 \mathrm{C}$ gowin-liczba-nowych-doktorantow-spadnie.html; dostęp: 07.03.2020.

/// Touraine A. 2010. Solidarność. Analiza ruchu społeçnego, tłum. A. Krasiński, Europejskie Centrum Solidarności.

/// Urbański J. 2014. Prekariat i nowa walka klas. Przeobraz̧enia wspótczesnej klasy pracowniczej i jej form walki, Instytut Wydawniczy Książka i Prasa.

/// Ustawa z dnia 20 lipca 2018 r. Prawo o szkolnictwie wyæ̌szym i nauce.

/// Workers' Inquiry, „Viewpoint Magazine” 2013, nr 3.

/// Woś R. 2019. Wy ższa sækoła prekariatu. https://www.tygodnikpowszechny.pl/wyzsza-szkola-prekariatu-158097; dostęp: 10.03.2020.

/// Wright S. 2002. Storming Heaven. Class Composition and Struggle in Italian Autonomist Marxism, Pluto Press. 


\section{/// Abstrakt}

Intelektualista to figura związana $\mathrm{z}$ wieloma jeszcze do niedawna żywymi mitami. Karol Marks porzucający karierę mieszczańskiego akademika i dziennikarza, by na całe życie zostać politycznym wygnańcem (uchodźca??), György Lukács po upadku Rewolucji Węgierskiej oddający pióro, gdy oficer KGP prosi go o złożenie broni, Kuroń i Modzelewski piszący List do partii, za który spędzą lata w więzieniu, Sartre rezygnujący z nagrody Nobla... Dziś ta figura jest martwa, nie ma nic bardziej odległego od przywołanego toposu niż współczesny polski akademik, konformista i karierowicz produkujący teksty w sposób zbliżony do tego, w jaki robotnik fabryczny przy taśmie produkuje towary, w przeciwieństwie do tego ostatniego niezdolny jednak tak do refleksji, jak i do walki o cokolwiek, nawet o samego siebie. Wbrew jednak przekonaniu burżuazji, która sądzi, że „historia ongi istniała, ale dzisiaj historii już nie ma" i chętnie by poprzestała na obróceniu intelektualisty w swojego płatnego, najemnego robotnika, historia dopiero się rozpoczyna. Totalna alienacja, jaką jest podporządkowanie władz umysłowych akumulacji kapitału, wymaga totalnej rebelii.

Słowa kluczowe:

intelektualista, klasa pracująca, burżuazja, kapitalizm, wykształcenie, edukacja, uniwersytet, bezrobocie, reforma, operaizm, subsumpcja, ruch rewolucyjny

\section{/// Abstract}

\section{The Death of the Intellectual: At Last!}

Until recently, the "intellectual" was a figure associated with many myths. Karl Marx abandoned a career as a bourgeois academic and journalist to become a permanent political exile; György Lukács gave a pen to a KGB officer, after he had been asked to lay down arms; Kuroń and Modzelewski wrote a "Letter to the Party," and as a result they spent years in prison; Sartre declined the Nobel Prize... Now the figure of the intellectual is dead. The contemporary Polish academic could not be more distant from this topos. The contemporary Polish academic is a conformist and careerist producing articles in the same way a factory worker produces commodities. However, in contrast to the latter, the former is unable either to reflect on or to fight for anything, even himself. But although bourgeois economists believe that "There has been history, but there is no longer any" and will be content to convert intellectuals into wage labourers, history is only just 
beginning. Total alienation, the subsuming of the faculty of thought to the accumulation of capital, demands total rebellion.

Keywords:

intellectual, working class, bourgeoisie, capitalism, degree, education, university, unemployment, reform, operaismo, subsumption, revolutionary movement

/// Jacek Zych - doktorant w Instytucie Socjologii Uniwersytetu Warszawskiego. Pisze doktorat o świadomości i życiu codziennym pracowników biurowych oraz konfliktach klasowych w pracy biurowej. Interesuje się myślą operaistyczna, teorią zależności, analizami z zakresu systemu-świata, demokratyczną edukacją i historią społeczną lat 1960-1970.

ORCID: https://orcid.org/0000-0002-6106-3852

E-mail: j.zych@warszawa.so.gov.pl 